\title{
IMPLEMENTATION OF THEORY OF CONSTRAINT ON WAITING TIME OF PRESCRIPTION SERVICE
}

\author{
Implementasi Theory of Constraint pada Waktu Tunggu Pelayanan Resep Obat
}

\author{
*Alissa Sita Pertiwi', Thinni Nurul Rochmah² \\ ${ }^{1}$ IAKMI Jawa Timur, Indonesia \\ ${ }^{2}$ Faculty of Public Health, Universitas Airlangga, Indonesia \\ *Correspondence: alissa.sita.pertiwi-2015@fkm.unair.ac.id
}

\begin{abstract}
Background: Medical services provided within the Indonesian National Health Insurance programme or Jaminan Kesehatan Nasional (JKN) have been continuously improving for the past several years. One of them is pharmaceutical service in the Pharmacy Store for JKN patients at one hospital with the highest number of visitors in Surabaya. However, one preliminary study points out that patient waiting time for prescription services in the Pharmacy Store for JKN patients is longer than the national standard.

Aim: This study aims to investigate the causes for such delay in prescription services as one of pharmaceutical services in the Pharmacy Store for JKN patients at one hospital in Surabaya.

Methods: This is an observational descriptive research with a reference to the Theory of Constraints. The research was conducted from August 2017 to February 2018. The data were obtained from observations, interviews with one pharmacist and four pharmacy technicians, and waiting time for prescription service.

Results: The study finds that the longer waiting time is caused by inefficient division of jobs and workers and the lack of worker's discipline to work on time. The behaviors and habits of pharmacist and pharmacy technicians in drug preparation greatly affect patient waiting time, since the services still highly depend on manual human labor. Conclusions: Patient experience in prescription drug services is significantly influenced by the time spent waiting for the service provider. This study provides useful insights about constraint identification in pharmaceutical services, especially waiting time.
\end{abstract}

Keywords: Pharmaceutical service, Theory of Constraints, Patient waiting time.

\section{ABSTRAK}

Latar Belakang: Pelayanan Jaminan Kesehatan Nasional (JKN) terus berkembang dalam beberapa tahun belakangan ini. Salah satunya adalah pelayanan farmasi di Depo Farmasi JKN yang memiliki pengunjung paling banyak di salah satu RSU Surabaya. Diketahui bahwa waktu tunggu pasien untuk pelayanan resep obat di Depo Farmasi JKN melebihi standar nasional yang telah ditetapkan.

Tujuan: Penelitian ini bertujuan untuk menyelidiki penyebab munculnya kendala yang membuat alur pelayanan resep obat dalam pelayanan farmasi tertunda di Depo Farmasi JKN RSU di Surabaya.

Metode: Penelitian deskriptif observasional dilakukan menggunakan Teori Kendala sebagai acuan. Penelitian ini dilakukan dari Agustus 2017 sampai Februari 2018. Data didapatkan dari hasil observasi, interview kepada 1 apoteker dan 4 asisten apoteker, dan pengukuran lama pelayanan obat.

Hasil: Ditemukan penyebab lamanya waktu tunggu pasien yaitu manajemen pembagian pekerja yang kurang tepat dan kurangnya kedisiplinan pekerja dalam bekerja secara tepat waktu. Kebiasaan dan perilaku petugas farmasi dalam menyiapkan obat sangat mempengaruhi waktu tunggu pasien dalam pelayanan resep obat dikarenakan pelayanan tersebut masih bergantung pada proses manual yang dikerjakan oleh tangan manusia. Kesimpulan: Pengalaman pasien pada pelayanan resep obat sangat dipengaruhi oleh waktu yang dihabiskan untuk menunggu penyedia jasa pelayanan. Tulisan ini memberikan wawasan mengenai identifikasi kendala dalam pelayanan farmasi, terutama untuk waktu tunggu pelayanan farmasi.

Kata Kunci: Pelayanan farmasi, Teori kendala, Waktu tunggu pasien

Received: 31 July 2018 Accepted: 4 December 2018

\section{INTRODUCTION}

Hospitals around the world are currently facing several challenges, such as increased operation cost, lack of qualified medical staffs, and limited hospital facilities (Barrick, 2009; Niu, Peng and ElMekkawy, 2013). Pharmacy unit, as an integral part of patient care in a hospital, also suffers from such challenges (Olson, 2012). Pharmaceutical service in a hospital has the responsibility of dispensing and compounding the medications or any other diagnostic and therapeutic chemical substances that are used for medical activities (Griffin, 2012). More than fifty percent of all hospital incomes are originated from pharmaceutical management (Herjunianto, Wardhani and Prihastuty, 


\section{[DJAKI \\ JURNAL ADMINISTRA
KESHHATAN INDONEST \\ INDONESLAN IOURNAI L}

2014). At any given time, day or night, the pharmacy unit of a hospital often finds itself dealing with a large number of patients, which leads to overcrowding. One study points out that overcrowding in healthcare services can affect patient waiting time and patient dissatisfaction (Zhao et al., 2015).

Patients have to go through several consecutive stages in pharmaceutical service to get a pack of complete medication. During their time at the hospitals, patients experience long waiting time due to delays in several key factors, such as in pharmacy and in the unfair distribution of workload between the medical staffs (Liang et al., 2015). The Pharmacy Store for JKN patients is one of many Pharmacy Stores for outpatients in one particular hospital in Surabaya, which becomes the object of this study. The Pharmacy Store for JKN has the most visitors compared to the other Pharmacy Stores in this hospital. Indonesian Government has passed a regulation on the minimum service standard of pharmacy service to be used as a guide for hospitals in ensuring the quality of health services (Ministry of Health of RI, 2008). The standard waiting time of pharmacy services is 30 minutes for non-formulated drugs and 60 minutes for formulated drugs. A preliminary study on compliance to standards shows that the percentage of service performance in The Pharmacy Store for JKN patients is below $30 \%$. In other words, the waiting time of most pharmaceutical services is still longer than the established standard.

Patient flow examination had been researched several times to identify bottlenecks in order to improve healthcare work process (Kim et al., 2013; Bhattacharjee and Ray, 2014). Different methods have been proposed for the improvement of patient waiting times in pharmaceutical services (Purwanto et al., 2015; Loh et al., 2017). In Indonesia, some studies had measured patient waiting time of pharmaceutical service (Karuniawati et al., 2016; Astuti, 2017; Margiluruswati and Irmawati, 2017), and find out the causes of long waiting (Rizanti, 2012; Fitriah, Faramita and Wiyanto, 2016). This study, in particular, tries to expand the discussion by taking theory of constraints into account.

Theory of constraints is a systematic approach to find one or several constraints in a system and discover how to manage them. This theory analogically views an organization as a chain of interdependent processes, and this chain has a weak links that may limit the chain's overall performance (Hansen, Mowen and Guan, 2009). Developed by Dr. Eliyahu Goldratt, theory of constraints proposes some managerial concepts by focusing improvement efforts on the weakest links in the system (Gupta and Kline, 2008).

Theory of constraints uses five focusing steps to improve organizational performance by identifying the organization's constraints, exploiting the constraints, subordinating everything else to the decisions made in step 2, elevating the organization's constraints, and repeating the process as a new constraint emerges to restrict the output (Hansen, Mowen and Guan, 2009; Kim, Mabin and Davies, 2008).

The main purpose of this research is to investigate the cause for long waiting time in prescription services in the Pharmacy Store for JKN patients at a hospital in Surabaya using the first of five focusing steps in Theory of Constraints (i.e. identify the constraints). By examining drug dispensing flow, the study would identify how the system works and where the constraints occur and affect the entire drug dispensing process. Furthermore, this research also specifically examines the organization's resources that lead to the constraints, especially its human resources.

\section{METHOD}

This is a descriptive research that describes a case and its characteristics (Nassaji, 2015) to identify problems. The study was carried out in the Pharmacy Store for JKN patients at one hospital in Surabaya. A preliminary study done at the same hospital indicates a long drug dispensing time in its Pharmacy Store for JKN patients. This research was conducted from August 2017 until February 2018.

The object of this research is the drug dispensing system in the Pharmacy Store for JKN patients. The pharmacist and pharmacy technicians are the unit of analysis in this research. This research is a case study in which measurements, interviews, and observations are carried out as data collection processes. This research was conducted with a series of activities starting from receiving and reviewing the prescription to dispensing medicine. Since this research required a comprehensive observation to describe the cause of long prescription services spent in the Pharmacy Store for JKN patients, all research subjects with acceptable criteria were collected. The data collection was done in a course of one month, following the working days and hours in the Pharmacy Store for JKN patients from 8 am until 6 pm.

This research utilizes the theory of constraints as a point of reference. The first step in the theory, which is used in this research, is constraint identification. The research data were collected consecutively in several steps, such as measurement of patient waiting time, interview for constraint grouping, observation, and in-depth interview to identify the cause of constraint emergence. The first data is time measurement, where the time in drug dispensing workflow was measured from the first to the last step with a digital timer. The pharmacist and pharmacy technicians who took part in pharmaceutical services were involved in the measurement process. 


\section{[DJAKI JURNAL. ADMINISTRASI
KESEHATAN INDONESIA INDONESLAN IOURNAL \&}

The research focused on prescription service workflow as the reference. As shown in Figure 1, prescription service in the Pharmacy Store for JKN patients has six steps. The waiting time of prescription service was only calculated from 5 out of 6 steps, starting from prescription review until drugs dispensing. The time in which the patients take queue number was not included in the calculation, since it was done automatically by a ticket machine. In addition, the process of taking this the queue number was relatively very short, and so it was deemed insignificant. Processing time in dispensing stage was also not included in the measurement because early observations showed that the processing time did not have significant effect to the duration of prescription service as a whole.

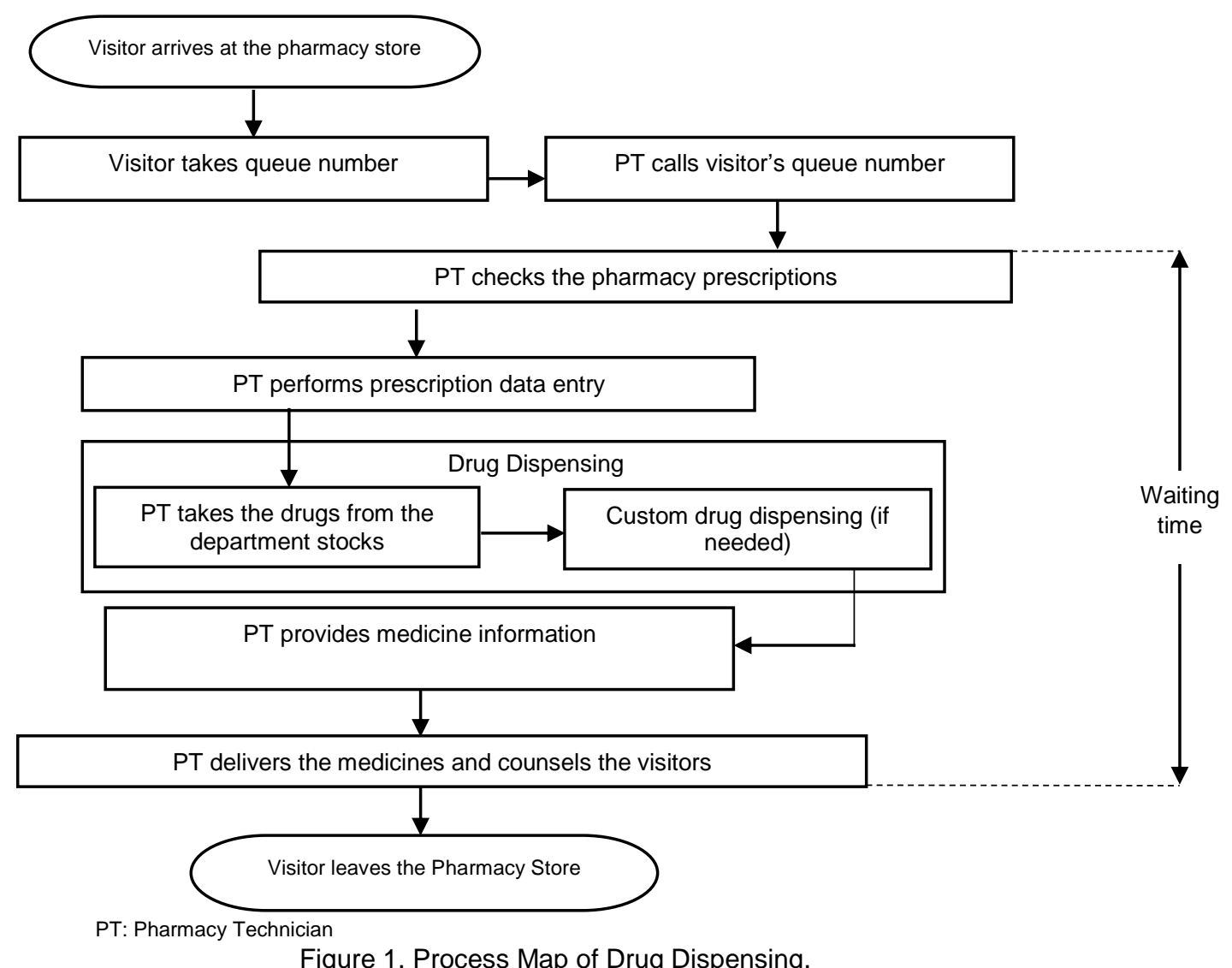

There were six steps of time measurement on service waiting time. The first step started from the visitor taking queue number until the visitor's queue number was called by the pharmacy technician. The second step was clocked after the pharmacy technician mentioned queue number and put patient's complete prescription files on a wide table. The third step started by the time the patient's prescription files were placed onto a wide table until the pharmacy data entry was completed. The fourth step started when the pharmacy technician received the prescriptions and placed the drugs in a small container and a packaging table. The calculation of this step also included customized drug formulation, whenever it was necessary according to the prescription. The fifth step began when the drugs were put on a packaging table, and the packed drugs were placed in a container to be brought by another pharmacy technician. The last step was counted for the time spent for placing the packed drugs in a container, calling out the visitors (patients/their families), and giving the medicines.
As an addition to time measurement, other data collection methods, such as in-depth interviews and observations, were also done to obtain additional information. All the acquired information were compared using triangulation. Triangulation was purposely used to examine whether the information gathered from time measurement was consistent with the one from interviews or observations, and vice versa (Basuki, 2016). Triangulation engaged multiple methods that will lead to more valid, reliable, and diverse construction of realities. By using multiple methods of data collection as triangulation, the researcher made an effort to gain a clear and comprehensive view of the phenomena (Cope, 2014).

Interviews were carried out to gather human experience (Brinkmann, 2014). One pharmacist and four pharmacy technicians working in the Pharmacy Store for JKN patients were interviewed using an observational descriptive methodology approach.

All of the respondents participating in the study were directly involved in the pharmacy data entry unit. Some opinions from the respondents 
related to the cause of constraint formation were genuinely based on their perspective and understanding without any influence from others. Variations appeared in some of the respondents' answers were also not limited by the researchers. Interview results were converted into several concise points based on the understanding and perceptions of the researchers. Similarities in opinions were further grouped and presented in a detailed table.

Observations were conducted on three random days to expose the behaviors and habits of pharmacy techniciants in the research site. Observation is an important activity to see behaviors, events, and physical characteristics of the respondents in normal circumstances (Centers for Disease Control and Preventation, 2008).

The data obtained from measurements and interviews were processed under two methods: tabulation and descriptive explanations. There were 3 formulas used in tabulation analysis for each step in prescription service: mean, minimum, and maximum value. Other variables such as service workflow, tabulation result, and identified constraints were later explained in detail using descriptive explanation approach. Further analysis other than waiting time measurement was limited only on the pharmacy data entry. This limitation had to be done since pharmacy data entry was the stage with the most significant waiting time as compared to other stages of prescription service.

\section{RESULTS AND DISCUSSION}

\section{Constraint Identifications in Drug dispensing}

Constraint identification process is one of several stages in Goldratt's theory of constraints (Şimşit, Günay and Vayvay, 2014). Carrying out an evaluation process is necessary in determining which resources are the constraint (Woeppel, 2016). Two methods can be used to identify the constraint: flow process diagram and time analysis approach. A flowchart design is commonly used for capacity evaluation of each stage in a system (Wilkin, 2009). One thing to consider is the capacity of a prescription service system is the time required at each stage. Therefore, time analysis can recognize which stage in a service takes the longest waiting time (Ronen, Pliskin and Pass, 2018). In this study, time frame is used a reference to determine the location of some constraints in prescription service. The waiting time measurement of prescription service consists of two criteria: the duration of queuing and the duration of prescription processing. The results are shown in Table 1.

Table 1. Time Measurement of the Prescription Service.

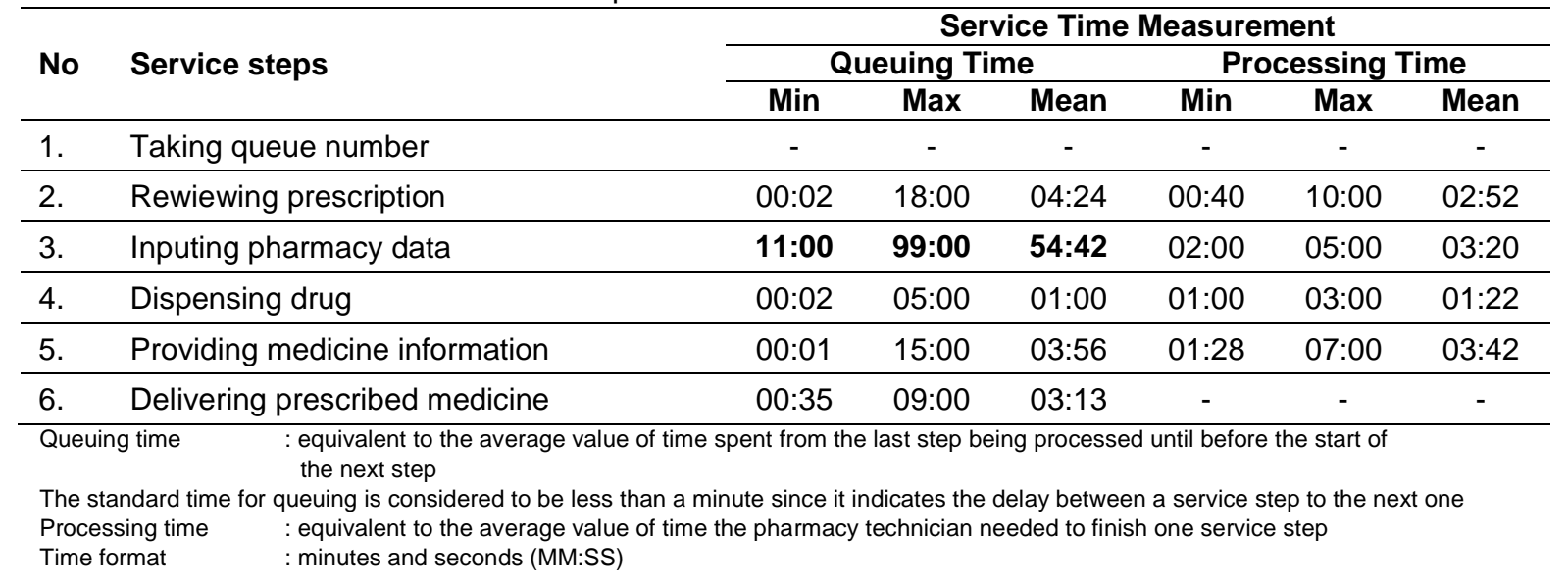

Table 1 points out congestions in five out of six total steps of prescription service. These congestions include constraints that lengthen service duration per step and affect overall patient waiting time. At steps one and two (queue number and prescription review), researchers find that the average duration for the pharmacy techinican to finish reviewing prescription is only two minutes and 52 seconds. However, observations show that the pharmacy technicians have a habit in calling 10 queue numbers simultaneously. This results in long queue of people with higher queue numbers. Observation on 19 December 2017 discovered that people with queue number 16 and 17 had to wait for 10 minutes.
Observation of pharmacy data entry on 15 December 2017 found out that nine prescriptions entered into the Pharmacy Store for JKN patients above 09.00 had to wait for more than 90 minutes to be inputted in the data entry. If it was earlier than 09.00, prescriptions only took approximately 11 minutes of waiting time. This research also finds that after a prescription file passed the checking step, it would be taken by the pharmacy technician randomly with varying amounts. This way of processing leads to disorderly work and increases the risk of long waiting time. Concerning the fifth step, observation on 15 December 2017 also found that one prescription was processed in 11 minutes 
before it finally started to be packed by the pharmacy technician.

The duration of drug dispensing can be identified from the time needed to prepare the appropriate medicine based on the prescription (Rahmawati and Wahyuningsih, 2016). In the six total steps, there were five constraints associated to the prescription service. It indicates that the duration of prescription service is important to determine the waiting time. From the five stages, all four stages with constraints require manpower, while the remaining one needs only a single ticket machine to print queue number for each visitor. Results shown in Table 1 depict that the most significant constraint occur in the third step of prescription service: the pharmacy data entry (the average value was 54 minutes 42 seconds). Because of time limitation, further analysis of the constraints in drug dispensing in the Pharmacy Store for JKN patients is limited only to the pharmacy data entry.

\section{Classification of Identified Constraints}

After identification process, the identified constraints were then categorized into two kinds of classifications. The first classification is based on internal and external sources (Hansen, Mowen and Guan, 2009). The second one is based on constraints in managerial systems, including resource, market, policy, and dummy constraint (Ronen, Pliskin and Pass, 2018). Based on interview results, most of the identified constraints correlated with internal human resources of the Pharmacy Store for JKN patients.

Table 2. Categorization of Identified Constraint.

\begin{tabular}{clccc}
\hline No. & \multicolumn{1}{c}{ Constraints } & $\mathbf{n}$ & $\%$ & Category \\
\hline 1. & $\begin{array}{l}\text { Pharmacy technician leaving the pharmacy data entry unit } \\
\text { with permission or leave quota }\end{array}$ & 4 respondents & $80 \%$ & $\begin{array}{c}\text { Internal, } \\
\text { Resource }\end{array}$ \\
\hline 2. & Pharmacy technician's tardiness & 4 respondents & $80 \%$ & $\begin{array}{c}\text { Internal, } \\
\text { Resource }\end{array}$ \\
\hline 3. & Data entry stage taking a long process & 2 respondents & $40 \%$ & $\begin{array}{c}\text { Internal, } \\
\text { Resource }\end{array}$ \\
\hline 4. & Variations in the duration of data entry & 2 respondents & $40 \%$ & $\begin{array}{c}\text { Internal, } \\
\text { Resource }\end{array}$ \\
\hline 5. & $\begin{array}{l}\text { Differences between drug inventory data in the system } \\
\text { (drug warehouse database) and actual drug stored at depot }\end{array}$ & 2 respondents & $40 \%$ & $\begin{array}{c}\text { Internal, } \\
\text { Resource }\end{array}$ \\
\hline 6. & $\begin{array}{l}\text { Pharmacy technician in data entry unit leaving the room to } \\
\text { help other units }\end{array}$ & 1 respondent & $20 \%$ & $\begin{array}{c}\text { Internal, } \\
\text { Resource }\end{array}$ \\
\hline $\begin{array}{l}\text { n } \\
\%\end{array}$ & $\begin{array}{l}\text { : number of respondents who give similar opinions } \\
\text { : percentages of respondents who give similar opinions }\end{array}$ & &
\end{tabular}

Constraints in the pharmacy data entry are classified into internal constraint category. According to observation results, the processing time of entry data stage is not influenced by external party such as the patient. It is, then, affected by internal resources within the Pharmacy Store for JKN patients itself: the personnel handling the prescription service.

The constraints in the pharmacy data entry are also classified into resource constraint category. This is because the data entry process was not fast enough to catch up with the demand for prescription service. Table 2 highlights that an internal resource responsible for the constraint in the service system is human resources. Because of the limited resources in this research, further analysis is limited to two stages with the highest number of votes: constraints number 1 and 2 .

\section{Causes of Constraints}

Conducting in-depth analysis of human resources is a way to determine the cause of constraints within the Pharmacy Store for JKN patients. In the processes depicted in Table 2, further explanations are limited to point 1 and 2, which are about the absence of pharmacy technicians in the pharmacy data entry unit and their tardiness.

\section{The Absence of Pharmacy Technicians in the Pharmacy Data Entry Unit with Permission or Leave Quota}

During the in-depth interview, some pharmacy technicians complained about other personnel being absent during the end of the year because the said personnel were taking their annual leave quota. Since 4 pharmacy technicians were not present in the prescription service unit, others had to work harder to cover all the tasks. There are two respondents' statements concerning the absence of the pharmacy technicians. Here are the translated statements:
“...there are so many holiday/day off this December, and many pharmacy technicians are absent from work for their annual leave. This depot is closed during holidays, so once opened, there will surely be a surge in the number of visitors. Moreover, the absence of some pharmacy technicians will worsen this situation."
"...in this pharmacy data entry unit, sometimes there are only 2 personnel available to provide service in the morning. Another one will come at 
noon, so the total number of personnel working in one day is 3 out of 5 people. In addition, when this depot opens after a holiday or two, we have to deal with the huge number of prescription. That is why sometimes we extend our shift to complete all the works."

The respondents stated that pharmacy technicians in the pharmacy data entry unit taking a day off would bring difficulties for others. It slows down data entry service. Since the research was done in December, some pharmacy technicians did not come every day to Pharmacy Store for JKN patients. During the 3-days observation, it was observed that there were always one or more pharmacy technicians who took a day off from work every single day.

Table 3. Observation on the behaviors of pharmacy technicians in the entry data unit.

\begin{tabular}{|c|c|c|c|c|}
\hline \multirow[b]{2}{*}{ No. } & \multirow[b]{2}{*}{ Observations } & \multirow[b]{2}{*}{ Number of Absentee } & \multicolumn{2}{|c|}{ Readiness of Pharmacy Technicians } \\
\hline & & & Time & $\begin{array}{c}\text { Total of pharmacy technicians in } \\
\text { morning shifts }\end{array}$ \\
\hline \multirow[b]{2}{*}{1.} & \multirow[b]{2}{*}{ First Day } & \multirow[b]{2}{*}{2 people } & 08.30 & 2 persons \\
\hline & & & 10.00 & $\begin{array}{l}2 \text { persons }+1 \text { person from afternoon } \\
\text { shift }\end{array}$ \\
\hline \multirow[b]{2}{*}{2.} & \multirow[b]{2}{*}{ Second Day } & \multirow[b]{2}{*}{2 people } & 09.00 & 1 person \\
\hline & & & 10.00 & $\begin{array}{l}1 \text { person }+1 \text { person from morning shift }+ \\
1 \text { person from afternoon shift }\end{array}$ \\
\hline \multirow{2}{*}{3.} & \multirow{2}{*}{ Third Day } & \multirow{2}{*}{3 people } & 08.30 & 1 person \\
\hline & & & 09.00 & 1 person +2 persons from morning shift \\
\hline
\end{tabular}

Table 3 and the process map present the number of absent pharmacy technicians. The total number of pharmacy technicians in the Pharmacy Store for JKN patients are 15 people. Since there are five steps in prescription services, they are divided into five different sections. Three people are assigned to the unit for medicine order review, five people in the pharmacy data entry unit, three people in the dispensing unit, two people in the medicine information unit, and two people in the distribution unit. The pharmacy data entry has the highest number of pharmacy technicians. However, researchers discovered that although the pharmacy data entry unit has more pharmacy technicians, the head of the Pharmacy Store for JKN patients will ask one of them to move and help other units if necessary.

\section{"If some pharmacy technicians take a day off, I am obliged to take one staff from data entry unit to take over the leaving personnel's job on that day. Because if I take a staff from any other unit, I am afraid that it will only have one person left, or even none at all..."}

The interview with the head of the Pharmacy Store for JKN patients also shows that the more pharmacy technicians from any other sections take a day off, the less likely for pharmacy technicians in the pharmacy data entry unit to do their own job. If many pharmacy technicians in the pharmacy data entry unit move to other sections, the remaining pharmacy technicians will have to deal with all the workload in the unit.

It can be concluded that the unfair distribution of personnel in the store can become the cause of long processing time in the pharmacy data entry unit. This is because the number of pharmacy technicians who take a day off will directly affect the number of personnel in the unit.
Furthermore, the risk of constraint will become higher if pharmacy technicians work slowly in entering data.

Labor distribution is one of several factors affecting the work effectiveness (Hardiyanti, 2017), which is defined as the utilization of resources in certain amount to produce some goods or services with certain quality in proper time (Siagian, 2012). Through balanced allocation of workload, an organization can create a good working atmosphere and avoid gaps between employees (Susanty and Baskoro, 2013). Increasing utilization of providers and reducing patient waiting time can also enhance the productivity of healthcare systems (Lakshmi and Sivakumar, 2013).

\section{Personnel's Tardiness}

Some respondents mentioned that the long data entry was due to personnel being late for morning shift. These are some respondents' opinions, which had been translated by the researchers:

\section{"...the morning shift staffs are not ready to work immediately. The pharmacy technicians are having breakfast or conversing with others shortly after they come to this depot. Because of that, they delay the processing of the first prescription file in the entry data stage." \\ "...sometimes the pharmacy technicians available in the store are just a few since the rests are still having their breakfast..."}

The two statements above indicate that there is a habit of taking a long time for the pharmacy technicians to be ready for work. They do various non-work-related activities before they are finally 
ready to work in drug dispensing. One respondent also pointed out that few pharmacy technicians in the Pharmacy Store for JKN patients are actually idling.

\begin{abstract}
"In this Pharmacy Store for JKN patients, we don't have enough number of personnel and we have to serve many patients. Some pharmacy technicians sometimes take a day off or do personal things such as having breakfast or going out instead"
\end{abstract}

These statements are supported with observations on the behaviors of pharmacy technicians in the morning shift. The Pharmacy Store for JKN patients opens from 08.00 in the morning. Even though the pharmacy technicians in the morning shift come mostly at 07.30 or 08.00 , they do not immediately go to their office when the depot is already open for patient's prescription service. Based on the work shift schedule put on the announcement board in the research area, the morning shifts for data entry service consist of three people. Thus, it can be assumed that there will be three pharmacy technicians being ready at their desks in the data entry unit at 08.00. Observation results on personnel punctuality (morning shift) are presented in Table 3.

Table 3 shows that all morning-shift pharmacy technicians in the pharmacy data entry unit were late to be ready on their workstations at 08.00. Further observation shows that shortly after they come and put their belongings in their locker, they still do things unrelated to their job. Pharmacy technicians in the data entry unit have to do their job earlier than some others. This is because data entry is one of the stages that occur at the beginning of the service. Delayed service in data entry will cause a major impact on the following services.

Since prescription services have to be done systematically, the delay in data entry will result in domino effect. Delays at one stage will result in delays at the next stage. Unfortunately, service delay in the data entry is caused by a lack of discipline. This result is in line with other study which indicates that there is a significant influence between discipline in workplace and employee performance (Azwar, 2015). A high level of discipline reflects on how much a worker feels responsible for the task assigned to him/her. This attitude encourages working passion and spirit (Dila and Rochmah, 2015).

\section{CONCLUSION}

The waiting time of prescription service in the Pharmacy Store for JKN patients at one of hospitals in Surabaya is analyzed using three steps. There are several constraints in five out of six steps of the service. The analysis is limited to the constraints in the data entry. The long waiting time in the data entry stage are caused by the unfair distribution of workload and the personnel's lack of discipline. There are some limitations in this study. First, the researchers cannot find the standard time reference for each step of drug prescription services.
Published by Universitas Airlangga doi: 10.20473/jaki.v7i1.2019.1-8

Moreover, there is no valid standard about the amount of workers, their skills, and the facilities that have to be fulfilled in any situation, whether during peak or off-peak hours of the services. Another limitation is the explanations of causes of constraints. Further analysis is limited only to the pharmacy data entry although constraints are identified in five steps of drug dispensing. Further research doing comprehensive analysis on all pharmacy service aspects is needed in order to obtain better understandings and solutions.

\section{CONFLICT OF INTEREST}

The authors declare that they have no conflict of interest

\section{REFERENCES}

Astuti, H. (2017) 'Evaluasi Waktu Tunggu Pelayanan Resep di Puskesmas Kalibawang Kabupaten Kulon Progo Daerah Istimewa Yogyakarta Bulan Februari 2017', AKFARINDO, 2(2), pp. 26-30.

Azwar, H. (2015) Pengaruh Disiplin Kerja Terhadap Kinerja Karyawan di Hotel Grand Inna Muara Padang. Undergraduate Thesis. Universitas Negeri Padang.

Barrick, I. J. (2009) Transforming Health Care Management: Integrating Technology Strategies: Integrating Technology Strategies. Sundburry: Jones \& Bartlett Learning.

Basuki (2016) Metode Penelitian Akuntansi dan Manajemen Berbasis Studi Kasus. 1st edn. Airlangga Universitty Press.

Bhattacharjee, P. and Ray, P. K. (2014) 'Patient flow modelling and performance analysis of healthcare delivery processes in hospitals: A review and reflections', Computers \& Industrial Engineering, 78, pp. 299-312.

Brinkmann, S. (2014) 'Interview', in Teo, T. (ed.) Encyclopedia of Critical Psychology. New York, NY: Springer New York, pp. 10081010.

Centers for Desease Control and Preventation (2008) 'Data Collection Methods for Program Evaluation: Observation', eTA Evaluation Briefs, (16).

Cope, D. G. (2014) 'Methods and Meanings: Credibility and Trustworthiness of Qualitative Research', Oncology Nursing Forum, 41(1), pp. 89-91.

Desselle, S. P. and Zgarrick, D. P. (2009) Pharmacy Management: Essentials for All Practice Settings. 2nd edn. New York: McGraw-Hill.

Dila, A. N. and Rochmah, T. N. (2015) 'Analisis Pengaruh Komunikasi, Kepemimpinan, dan Tim Kerja Terhadap Kedisiplinan Pegawai Rumah Sakit X Surabaya', Jurnal Administrasi Kesehatan Indonesia, 3(2), pp. 129-138.

Fitriah, N., Faramita, N. I. and Wiyanto, S. (2016) 'Penyebab dan Solusi Lama Waktu Tunggu Pelayanan Obat di Instalasi Farmasi Rawat Jalan Rumah Sakit', jurnal Kedokteran Brawijaya, 29(3), pp. 245-251.

Griffin, D. J. (2012) Hospital: What They Are and 
How They Work. 4th edn. San Marcos: Jones and Bratlet Learning.

Gupta, M. and Kline, J. (2008) 'Managing a community mental health agency: A Theory of Constraints based framework', Total Quality Management \& Business Excellence. Routledge, 19(3), pp. 281-294.

Hansen, D. R., Mowen, M. M. and Guan, L. (2009) Cost Management: Accounting \& Control. 6th edn. Mason: South Western Cengage Learning.

Hardiyanti, R. (2017) 'Pengaruh Pembagian Kerja dan Pengawasan terhadap Efektivitas Kerja Pegawai di Kantor Kecamatan Sangatta Utara Kabupaten Kutai Timur', e-journal Pemerintah Integratif, 5(4), pp. 570-580.

Herjunianto, Wardhani, V. and Prihastuty, J. (2014) 'Faktor yang Mempengaruhi Cakupan Layanan Farmasi di Instalasi Rawat Jalan Rumah Sakit', Jurnal Kedokteran Brawijaya, 28(1), pp. 8-14.

Karuniawati, H. et al. (2016) 'Evaluasi Pelaksanaan Standar Pelayanan Minimal (SPM) Farmasi Kategori Lama Waktu Tunggu Pelayanan Resep Pasien Rawat Jalan di RSUD Kota Salatiga', Kartika-Jurnal IImiah Farmasi, 4(1), pp. 20-25.

Kim, E. et al. (2013) 'Discovery of Outpatient Care Process of a Tertiary University Hospital Using Process Mining', Healthc Inform Res. The Korean Society of Medical Informatics, 19(1), pp. 42-49.

Kim, S., Mabin, V. J. and Davies, J. (2008) 'The theory of constraints thinking processes: retrospect and prospect', International Journal of Operations \& Production Management, 28(2), pp. 155-184.

Lakshmi, C. and Sivakumar, A. I. (2013) 'Application of queueing theory in health care: A literature review', Operations Research for Health Care, 2(1), pp. 25-39. Liang, B. et al. (2015) 'Improvement of chemotherapy patient flow and scheduling in an outpatient oncology clinic', International Journal of Production Research. Taylor \& Francis, 53(24), pp. 7177-7190. 10.1080/00207543.2014.988891.

Loh, B. C. et al. (2017) 'Impact of Value Added Services on Patient Waiting Time at the Ambulatory Pharmacy Queen Elizabeth Hospital', Pharmacy Practice, 15(1), pp. 1-7. doi: 10.18549/PharmPract.2017.01.846.

Management Sciences for Health (2012) MDS-3: Managing Access to Medicines and Health Technologies. Edited by M. Embrey. Arlington, VA: Management Sciences for Health.

Margiluruswati, P. and Irmawati, L. I. (2017) 'Analisis Ketepatan Waktu Tunggu Pelayanan Resep Pasien JKN dengan Standar Pelayanan Minimal Rumah Sakit 2017 (Studi di UPF Rawat Jalan RSUD Bhakti Dharma Husada)', Jurnal Manajemen Kesehatan Yayasan RS. Dr. Soetomo, 3(1), pp. 115-126. doi:10.29241/jmk.v3i1.84

Ministry of Health of Republic Indonesia (2008) Standar Pelayanan Minimal Rumah Sakit.
Indonesia.

Nassaji, H. (2015) 'Qualitative and descriptive research: Data type versus data analysis', Language Teaching Research, 19(2), pp. 129-132. doi: $10.1177 / 1362168815572747$.

Niu, Q., Peng, Q. and ElMekkawy, T. Y. (2013) 'Improvement in the Operating Room Efficiency using Tabu Search in Simulation', Business Process Management Journal, 19(5), pp. 799-818. doi: 10.1108/BPMJ-Nov2011-0081.

Purwanto, H. et al. (2015) 'Faktor Penyebab Waktu Tunggu Lama di Pelayanan Instalasi Farmasi Rawat Jalan RSUD Blambangan', Jurnal Kedokteran Brawijaya, 28(2), pp. 159162.doi:http://dx.doi.org/10.21776/ub.jkb.201 5.028 .02 .8

Rahmawati, I. N. and Wahyuningsih, S. S. (2016) 'Faktor Pelayanan Kefarmasian dalam Peningkatan Kepuasan Pasien di Pelayanan Kesehatan', Indonesian Journal on medical Science, 3(1), pp. 88-95.

Rizanti, H. E. (2012) Analisis Faktor Penyebab Lama Waktu Tunggu Pelayanan Resep di Unit Farmasi Rawat Jalan Rumah Sakit PHC Surabaya. Undergraduate Thesis.Universitas Airlangga.

Ronen, B., Pliskin, J. S. and Pass, S. (2018) The Hospital and Clinic Improvement Handbook: Using Lean and the Theory of Constraints for Better Healthcare Delivery. New York: Oxford University Press.

Siagian, S. P. (2014) Manajemen Sumber Daya Manusia. Jakarta: Bumi Aksara.

Şimşit, Z. T., Günay, N. S. and Vayvay, Ö. (2014) 'Theory of Constraints: A Literature Review', Procedia - Social and Behavioral Sciences, 150(231), pp. 930-936.

Susanty, A. and Baskoro, S. W. (2013) 'Pengaruh Motivasi Kerja dan Gaya Kepemimpinan Terhadap Disiplin Kerja Serta Dampaknya Pada Kinerja Karyawan (Studi Kasus Pada PT. PLN (Persero) APD Semarang)', J@tii Undip: Jurnal Teknik Industri, 7(2), pp. 77-84

Woeppel, M. (2001) Manufacturer's Guide to Implementing the Theory of Constraints. Boca Raton: CRC Press LLC.

Zhao, Y. et al. (2015) 'Bottleneck detection for improvement of Emergency Department efficiency', Business Process Management Journal, 21(3), pp. 564-585. 